\title{
KNOWLEDGE, ATTITUDE AND PRACTICE OF SELF-MEDICATION AMONG MEDICAL STUDENTS DURING EXAM TIME
}

Ashish Kumar Bhattarai ${ }^{1, *}$, Prabin Kumar Karki ${ }^{2}$

${ }^{1}$ Department of Pharmacology, Kathmandu Medical College, Duwakot, Bhaktapur, Nepal

${ }^{2}$ Departmant of Biochemistry, Kathmandu Medical College, Duwakot, Bhaktapur, Nepal

Received: 26 Jun, 2020
Accepted: 2 Aug, 2020
Published: 27 Sept, 2020
Key words: Exam; Medical students; Self- Medication.
*Correspondence to: Ashish Kumar Bhattarai,
Department of Pharmacology, Kathmandu Medical
College, Duwakot, Bhaktapur, Nepal.
Email: ashishakb33@gmail.com
Citation
Bhattarai AK, Karki PK. Knowledge, attitude and
practice of self-medication among medical stu-
dents during exam time. Journal of Chitwan Medi-
cal College.2020;10(33):25-8.

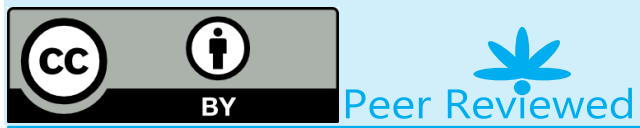

\section{INTRODUCTION}

Self-medication is defined as procurement and consuming drugs without the advice of a physician for diagnosis, prescription or surveillance of treatment. ${ }^{1,2}$ This includes consuming medicines without prescription, reusing expired prescriptions, sharing medicines with friends and relatives or using left over drugs stored at home. ${ }^{3}$ Inappropriate self-medication also causes wastage of resources, increase resistance of pathogens and generally cause serious health hazards such as adverse drug reactions, prolonged suffering and drug dependence. ${ }^{4}$

There are many explanations for the increased possibility of self-medication among medical students. They have easy access to information from drug indices, literature, and easy accessibility. ${ }^{3.4}$ Medical education being one of the toughest examination modules all over the world can be stressful to many students. ${ }^{6}$ Many experience medical conditions like anxiety, palpitation, restlessness and increased gastric secretions. There are even chances of taking psycho stimulants by some students to enhance cognitive functions. ${ }^{9}$ Many have tendency to take drugs for gaining wakefulness to increase study span. Many studies have showed that inappropriate self-medication causes wastage of resources, increases resistance of pathogens and generally causes serious health hazards such as adverse drug reactions, prolonged suffering and drug dependence. ${ }^{3-5}$

There is scarcity of studies on self-medication among medical students during the exam times. This subject can be startling issue but a concealed truth. This study objective was to identify the reasons, pattern, attitude and their knowledge of selfmedication during the exam time.

\section{METHODS}

This study was a questionnaire-based study approved by the Research and Ethics Committee of the Kathmandu Medical College. This study was conducted among the first and second year MBBS and BDS Students of Kathmandu Medical College from May 2020 to June 2020. A semi-structured questionnaire consisting both open and closed ended items was used. The questionnaire was inculcated from published articles ${ }^{11,13}$ and the questionnaire was finalized by the faculty members of the department of Pharmacology. It was pretested among small group of ten students to look for the understanding and accep- 
tance by the students. These ten students were not included in the study. Based upon the response of the pretesting, minor modification on the questionnaire was done and the final questionnaire to be used in study was prepared.

A twenty-two item Semi- structured questionnaire comprising four sections was used to achieve the study objectives. First section comprised the six item demographic details, second section included the five items to look for the knowledge. Third section comprised six items to look for the attitude and practice while last section included four items to look for the reason of self-medication and its adverse consequences. Owing to the COVID-19 pandemic as the academics were closed an online version of the questionnaire was prepared using google forms and then sent to the first and second year BDS and MBBS students in their Viber groups. The written online consent was also attached with the online version. Data was collected, compiled and analyzed by using Statistical Package of Social Science (SPSS) version 20 . The data was analyzed using descriptive statistics. The results were tabulated where necessary.

\section{RESULTS}

Total number of participating students was 90. Of them 32(35.6\%) were MBBS Second year, 26(28.9\%) MBBS first year, $16(17.8 \%)$ BDS first year and $16(17.8 \%)$ BDS second year. Of the participants $47(52.2 \%)$ were female candidates and $43(47.8 \%)$ male candidates.

Table 1: Socio-demographic characteristics of study population

\begin{tabular}{|l|l|c|}
\hline \multicolumn{2}{|l|}{ Socio demographic factors } & $\begin{array}{c}\text { Number of students } \\
(\%)\end{array}$ \\
\hline \multirow{2}{*}{ Gender } & Male & $43(47.8)$ \\
\cline { 2 - 3 } & Female & $47(52.2)$ \\
\hline \multirow{2}{*}{ Year } & First & $42(46.67)$ \\
\cline { 2 - 3 } & Second & $48(53.33)$ \\
\hline \multirow{2}{*}{ Program } & MBBS & $58(64.44)$ \\
\cline { 2 - 3 } & BDS & $32(35.55)$ \\
\hline
\end{tabular}

Table 2: Knowledge and pattern of self-medication among the participants

\begin{tabular}{|l|c|c|}
\hline $\begin{array}{l}\text { Knowledge and patterns of self- } \\
\text { medication }\end{array}$ & Yes & No \\
\hline Take medication during exam time & $16(17.7)$ & $\mathbf{N}(\%)$ \\
\hline $\begin{array}{l}\text { Read medication leaflet before } \\
\text { use }\end{array}$ & $68(75.6)$ & $22(24.4)$ \\
\hline $\begin{array}{l}\text { Follow the dosage directions } \\
\text { properly }\end{array}$ & $71(78.7)$ & $19(21.3)$ \\
\hline Awareness of side effects & $73(81.25)$ & $17(18.75)$ \\
\hline $\begin{array}{l}\text { Long term use OTC drug cause } \\
\text { side effects }\end{array}$ & $87(96.7)$ & $3(3.3)$ \\
\hline
\end{tabular}

The respondents perceived several advantages and disadvantages of self-medication (Table 1 ). The most important advantage in favor of self-medication were minor condition to be consulted $(39.4 \%)$, having the self-confidence about the knowledge of the drug (21\%), saving time (20.6\%), do not want to consult doctor (10.4\%) and other (8.6\%).

The disadvantage of self-medication was perceived as the risk of side effects and risk of using inappropriate drugs as presented in table 2. Most of the participants $96.7 \%$ were aware of long term adverse consequence of OTC drugs. 84 (93.33\%) patient are aware of the likelihood of the side effects while $6(6.67 \%)$ are not aware of the possibility of the side effects.

The majority of the respondents $73(83.3 \%)$ had negative attitude like chances of adverse effects, misuse and dependency towards the self-medication saying it is unacceptable while $15(16.7 \%)$ respondents thinks it is acceptable as it is convenient and fells better after self-medication during the exam time. Of the 90 respondents only $20(22.22 \%)$ were devoid of any conditions during exam time. Most of them had anxiety $40(44.44 \%)$, followed by headache $17(18.88 \%)$, GI problems $16(17.77 \%)$, Insomnia $7(7.77 \%)$, nausea and vomiting $3(3.33 \%)$, palpitation $3(3.33 \%)$, others $7(7.77 \%)$. Out of them $25(27.77 \%)$ had more than one symptoms.

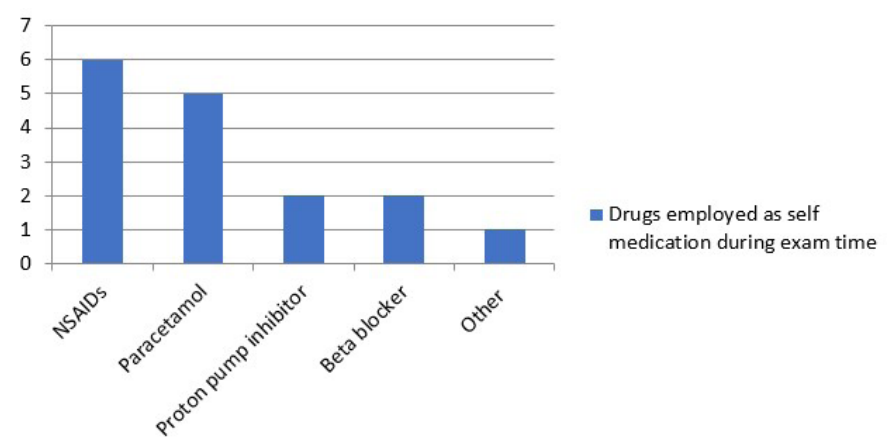

Figure 1: Drugs employed as self-medication during exam time

Table 3: Source of self-medication during the exam time

\begin{tabular}{|l|c|}
\hline $\begin{array}{l}\text { Source of self-medication during } \\
\text { the exam time }\end{array}$ & $\begin{array}{c}\text { Number of stu- } \\
\text { dents (\%) }\end{array}$ \\
\hline Text book & $6(37.5)$ \\
\hline Internet & $4(25)$ \\
\hline Pharmacy & $2(12.5)$ \\
\hline Friends / senior suggestions & $2(12.5)$ \\
\hline Others & $2(12.5)$ \\
\hline
\end{tabular}

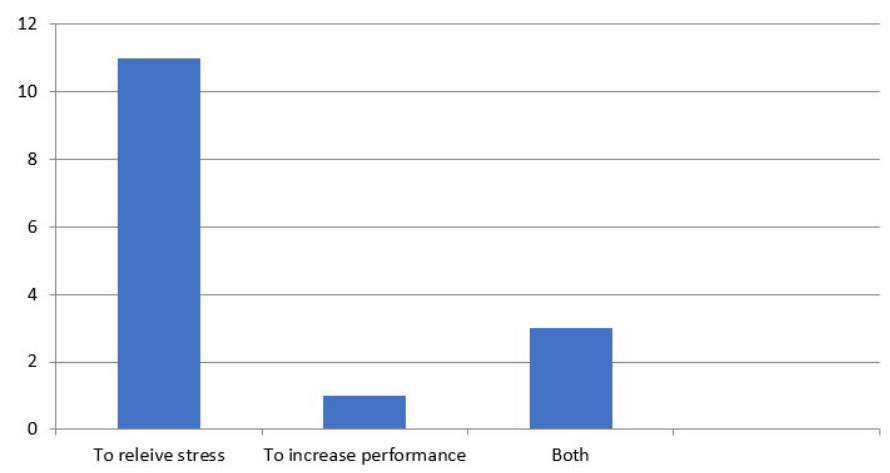

Figure 2: Reasons for self-medication during the exam time 
The source of their knowledge about the drugs they are taking for self-medication during exam times is as presented in table 3. Out of 16 participants who takes the medicine during exam time $6(37.5 \%)$ has experienced the side effects.

\section{DISCUSSION}

Medical education is one of the toughest education systems. Here the students undergo many demanding conditions which can create stress and pressure on them which can make them liable for taking many types of medicines. ${ }^{7}$ Medical students thus had higher depression rates than the general population. ${ }^{7}$ They can have stress and anxiety related symptoms like palpitation, severe anxiety, insomnia, restlessness, stress related increase gastric acidity. Stress and anxiety can worsen many existing diseases as well such as depression, gastrointestinal disease, asthma, heart diseases. This can also lead to deprive sleep related symptoms like headache, dizziness, etc. and it can make the existing anxiety and depression even worse. Due to pressure of exams many might also have possibility to take the drugs that cause insomnia like caffeine, psycho-stimulants, amphetamine, beta blockers, decongestants etc, so that they can make more hours for their studies. ${ }^{8,9}$ So the students who are facing these situations can make self-diagnosis or to cope up with the difficult situation can lead to self-medication without seeking proper medical channel. The data further reflect an increasing trend toward self-medication among college students.A substantial percentage reported using over the counter (OTC) medications (74.1\%), herbal or dietary supplements (70.6\%). ${ }^{8}$ And because health care students are associated with higher medical knowledge, have higher possibility of seeking any kind of self-medication. ${ }^{14}$ In some reports the drugs like methylphenidate was used by the students up to $16 \%$ to improve the cognition. ${ }^{9}$ Sleep deprivation, poor sleep quality are common among clinical year's medical students. High levels of stress and the pressure of maintaining grade point averages may be influencing their quality of sleep. ${ }^{10}$ Being medical students they are also aware of existence of cognitive enhancer drugs. The combination of increased exam pressure and stress with their accessibility and knowledge of drugs makes this group very vulnerable for the irrational drug use and sometimes also for drug abuse. ${ }^{9}$

The respondents had good knowledge of the advantage and disadvantage of self-medication. Many of them perceived selfmedication as easier and convenient alternative for overcoming their symptoms. $96.7 \%$ were aware of the long term consequences of the self-medications. In a similar study, done in Kathmandu medical college, $80.8 \%$ thought that self-medication was a part of self care and $89.4 \%$ planned to continue selfmedication and $99 \%$ of the participants had self medicated at some point of their lifetime. ${ }^{12}$ From these data we can assume the scenario where although the participants has knowledge of the consequences of the self-medication but still they are practicing to much large extent.

Majority of the participants $75(83.3 \%)$ had negative attitude towards the use of any sort of self-medication. They are not willing to take the self mediations due to concern about the likeliness of adverse events, misuse and dependency.68(75.6\%)students read the medicine leaflet before use and $71(78.7 \%)$ followed the dosage directions properly. In the similar study Almalak et al.in 2014 a study done in Saudi Arabia, 85.2\% were aware that long term use of OTC drugs can cause serious side effects. ${ }^{11}$

In this study only $17.7 \%$ practiced self-medicine during exam time. And most of them were taking the NSAIDs followed by proton pump inhibitors and beta blockers. In the study by Almalak et al. nearly $80 \%$ students disclosed the usage of NSAIDs during the exam time for the relief of headache. ${ }^{11}$ Most of them were taking the medicines to relief the problems due to stress of the exam. The most common source of the information about the medication was textbooks followed by internet and pharmacy sources.In the study by Badigarin 2012, maximum number(39\%) were found to derive the information from textbook. The most common drugs that were used as self-medication were analgesic and antipyretics. ${ }^{13}$ Ease of access to the OTC drug was regarded as the main contributory factor by Almalak et al. ${ }^{11}$

It was interesting that although good proportion of respondents had the symptoms like insomnia (7.77\%), nausea and vomiting $(3.33 \%)$ and other $(7.77 \%)$ there was no reported drug use for those conditions. This study suggests that students are more liable take the medicines for the headaches, gastric conditions and anxiety than other conditions. There was no response of the use of the cognitive enhancers except some use energy drinks. In this study it was not found the evidence of use of any substance abuse drugs by the students for the enhancement of their cognitive functions and to relieve from the exam induced stress. Exclusivity and relevance is the major strength of this study. Increment of the sample size and broadening to multi centric study could make this study even more compelling and persuasive.

\section{CONCLUSION}

This descriptive survey showed that the medical students had good knowledge about ill effects of the self-medication during the exam time. The attitude of them towards the selfmedication was negative and they quite know the drawback and consequences of this. Still the small number practicing the self-medications during the exam time suggests the existing false prerogative present in medical students that can lead to meager practice and awful consequences. And it would be interesting to evaluate the changes in the self-medication pattern during the exam time while students' progress through the medical school.

\section{ACKNOWLEDGEMENT}

The author would like to thank all the medical students who participated in this study and appreciate their cooperation to make this study possible.

\section{CONFLICT OF INTEREST: None}

FINANCIAL DISCLOSURE: None 


\section{REFERENCES:}

1. Shankar PR, Partha P, Shenoy N. Self-medication and nondoctor prescription practices in Pokhara valley, Western Nepal: a questionnaire based study. BMC Fam Pract. 2002;3:17. [DOI]

2. Montastruc JL, Bagheri H, Geraud T, LapeyreMestre M. Pharmacovigilance of self-medication. Therapie. 1997;52(2):105-10. [PMID]

3. James H, Handu SS, Khalid AJ, Khaja A, Otoom S, Sequeira RP. Evaluation of the knowledge, attitude and practice of self-medication among first year medical students. Med PrincPract. 2006;15(4):270-5. [DOI]

4. Hughes CM, McElnay JC, Fleming GF. Benefits and risks of self-medication. Drug Saf. 2001;24(10):1027-37. [DOI]

5. Hem E, Stokke G, Tyssen R, Grønvold NT, Vaglum P, Ekeberg O. Self prescribing among young Norwegian doctors: a nine year follow up study of a nationwide sample. BMC Med. 2005;3:16. [DOI]

6. Saipanish R. Stress among medical students in a Thai medical school. Med Teach. 2003;25:(5):502-6. [DOI]

7. Dahlin M, Joneborg N, Runeson B. Stress and depression among medical students: a crosssectional study. Med Educ. 2005 Jun;39(6):594-604. [DOI]

8. Stasio MJ, Curry K, Sutton-Skinner KM, Glassman DM. Over-the-coun- ter medication and herbal or dietary supplement use in college: dose frequency and relationship to self-reported distress. J Am Coll Health. 2008;56(5):535-48. [DOI]

9. Finger $\mathrm{G}$, da Silva ER, Falavigna A. Use of methylphenidate among medical students: a systematic review.Rev Assoc Med Bras. 2013;59(3):285-9. [DOI]

10. Alsaggaf MA, Wali SO, Merdad RA, Merdad LA. Sleep quantity, quality, and insomnia symptoms of medical students during clinical years. Relationship with stress and academic performance. Saudi Med J. 2016;37(2):173-82. [DOI]

11. Almalak H, Albluwi Al, Alkhelb DA, Alsaleh HM, Khan TM, Azmi M, et al. Students attitude towards use of over the counter drugs during exams in Saudi Arabia. Saudi Pharm J.2014;22(2):107-12. [DOI]

12. Acharya J, Dixit SM, Ghimire S. Self-medication among undergraduate medical students: An alarming concern of "over the counter" drugs in Nepal. Nepal Med J. 2019;02(03):33-6. [LINK]

13. Badiger S, Kundapur R, Jain A, Kumar A, PatanashettyS, Thakolkaran N, et al.Selfmedication patterns among medical students in South India. AustralasMed J. 2012;5(4):217-20. [DOI]

14. Silva MG, Soares MC, Muccillo-Baisch AL. Self- medication in university students from the Rio Grande, Brazil. BMC Public Health. 2012; 12:339. [DOI] 